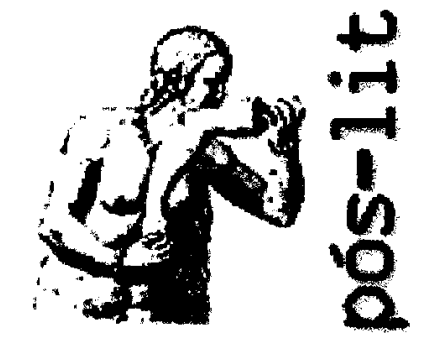

Programa de Pós-Graduação em Letras: Estudos Literários da Faculdade de Letras da UFMG

Artigo disponível em http://www.letras.ufmg.br/poslit

\section{REFLEXÕES SOBRE OS ESTUDOS LITERÁRIOS}

Maria Luiza Ramos $U F M G$

Dans ce texte on discute le prestige que subissent certains domaines des études littéraires, comme l'intertextualité et l'interdisciplinarité, ce qui n'est qu'un reflect du grand tableau sur lequel la fragmentation et le collage ont écrit la culture postmoderne. Parmi les études interdisciplinaires on met l'accent sur l'échange de concepts entre la littérature et la psychanalyse, le texte littéraire étant un lieu de plus pour les formations de l'inconscient. 


\section{DA POESIA}

Que a poesia não é objeto de consumo, isto se reflete de pronto na midia, de onde ela é praticamente excluída. Enquanto o drama se propaga no palco, ou através dos modernos recursos cênicos providos pela tecnologia da televisão, e a ficção narrativa é absorvida por esse novo meio de expressão, convertendo-se em novelas, seriados e mini-séries por horas e horas de exibição, a poesia está ausente da telinha. Um só fato é bastante, como se não houvesse outros, para ser impensável a absorção da poesia pela TV: a desconstrução da poesia se faz na sua produção. A colagem se deve ao poeta, que cada vez mais faz do seu texto o eco de outros textos mas um eco em que o ruído é o fator estruturante fundamental. A poesia não admite, pois, os cortes e a montagem que a televisão opera no produto já posto em circulação, destoando, portanto, daquele cenário esquizofrênico em que imagens distintas se sucedem com estonteante rapidez, superpondo-se não só umas às outras, mas à música, que passa a ser parte integrante da mensagem.

E aqui tocamos no ponto principal: a mensagem

Pelo fato de a palavra poética ser multívoca - um feixe de significações - o sentido se produz de uma maneira dinâmica, que exclui um significado determinado. Assim, importa considerar sobretudo o significante, pois este, sim, é na sua materialidade fônica e visual o elemento concreto do texto, cuja recursividade pressupóe um processo mais complexo de decodificação que não se basta com o entendimento nem se esgota na sensibilidade. A linguagem poética, voltada sobre si mesma, não tem, pois, acolhida nos meios de comunicação, pelo próprio fato de não comunicar coisa alguma, pelo menos alguma coisa que possa ser relatada. Se o poema se faz com palavras, é entretanto no não dizer que se dá, não a comunicação, mas a comunhão poética, o que pressupõe também um leitor determinado. Essa linguagem cifrada, que faz do leitor um parceiro e um cúmplice, e que tem sua razão de ser na forma e na produção, está, pois, se enclausurando nesta cultura em que os valores são a matéria e a finalidade.

$\mathrm{Na}$ medida em que a informação ganha meios de expressão cada vez mais elaborados pela tecnologia da midia, e todo mundo quer saber mais e mais coisas, o que a poesia busca é o indizível, merecendo definições por sua vez poéticas como estas:

o poema é um ponto de suspensão; o poema moderno é habitado por um silêncio central.
Também um certo segmento da prosa literária, tradicionalmente caracterizada pela narrativa, vem disputando com a poesia esse dizer sem conceitos - aspiração que Marguerite Duras assim expressa:

Livros ilegíveis, inteiros, entretanto. Tão longe de qualquer palavra quanto o desconhecido de um amor sem objeto.

Assim, não é de estranhar-se que essa reação diante da torrente de informações não se confine em um determinado gênero, a ponto de se dizer que a literatura mais expressiva deste século se caracteriza como uma

literatura do silêncio, uma lira sem cordas, ${ }^{3}$

que faz evocar o jogo sem bola, de Cortázar, e o concerto sem som, de John Cage. ${ }^{4}$

Enquanto isto, um outro discurso, que tem explorado exaustivamente os chamados tropos, ou figuras de linguagem, o duplo sentido, os enunciados antitéticos, os trocadilhos, além de efeitos fônicos e visuais, faz da linguagem cifrada um meio de tornar a mensagem mais eficaz, apelando tanto para a emoção quanto para o entendimento. Tornar novo o já conhecido, através do exercício da percepção, esse o universo que a publicidade compartilha com a poesia, que, entretanto, se distancia diametralmente dela. Em vez da gratuidade do fazer poético, o discurso é aí movido pelo interesse, pela retórica - instrumento da persuasão. Apesar de certos recursos comuns no campo da linguagem verbal, a manipulação destes tem objetivos opostos, como se sabe desde Aristóteles, e, enquanto no poema prevalece o código, é na mensagem que se centram a propaganda e o anúncio, apelando ainda para a colagem tanto plástica quanto musical, o que faz da midia o seu espaço por excelência.

Onde, então, a poesia? Mesmo nos cursos universitários por onde transitam os estudantes de literatura, tenho observado que a poesia ocupa um reduzido espaço, devido tanto à falta de demanda quanto à escassez de oferta.

É certo que ensinar a poesia é, em tese, uma tarefa impossível.

\section{OURAS, 1993. p.22.}

3.HASSAN, 1993.0 .92

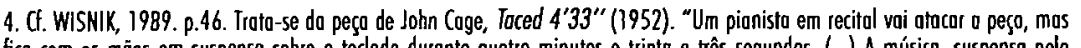
fica com os móos em suspenso sobre o teclado durante quatro minutos e trinta e três segundos. (...) A música, suspensa pela intérpreté, viro silênecio. 0 silêncio do plotéio vira rúido. 0 suído é o som" 
Como também não se pode ensinar a música, ou qualquer outra arte, apesar de a Universidade formar intérpretes e compositores. Os cursos de Letras, entretanto, são orientados para a pesquisa científica e não para a produção artística. Mas qualquer pessoa de mediano entendimento sabe que a experiência de quem ouve uma música sem conhecer coisa alguma da teoria musical é muito diferente de uma outra experiência em que, além de fruir pela sensibilidade, o ouvinte possa distinguir os modos, os tons, os temas e suas variações, os contrapontos, valorizando a mais insignificante modulação, num processo de escuta participante, que não se faz linearmente, mas segue de perto a recursividade da obra musical. Pois o mesmo acontece com a leitura da poesia, embora o preconceito contra a crítica pretenda levar ao descrédito os textos teóricos que buscam proporcionar conhecimentos relativos ao fazer poético, à especificidade dos fatores constituintes da obra literária. Quando se fala em analisar um poema, pensa-se apenas na "dissecação", enquanto, ao contrário, o mérito reside justamente no refazê-lo, operação sem a qual a análise não faria sentido. Como observou Roland Barthes, tomar o real, decompor e recompor é aparentemente muito pouca coisa. Entretanto, entre os dois tempos dessa atividade, ele se produz de novo. ${ }^{5}$ Tal reflexão, feita a propósito do estruturalismo, não se limita, por certo, a um determinado método de análise. A essas palavras me reportei, na introdução ao estudo fenomenológico da obra literária, por expressarem aquilo que eu sempre havia experimentado no ensino da literatura. ${ }^{6}$ E é esse, aliás, o procedimento de quantos se dediquem a investigar o modo de ser e o funcionamento de um determinado objeto.

Escritores como Borges, por exemplo, têm minimizado os estudos acadêmicos no campo da poesia, dizendo que há pessoas que a sentem escassamente e, em geral, se dedicam a ensiná-la. ${ }^{7}$ Nesse sentido, expressa mais ou menos a mesma coisa que Valéry, quando fala que,

infelizmente, entre aqueles que não têm grande apetite pela poesia, muitos se põem a julgá-la, a discorrer sobre ela, a distribuir, enfim, o que não tềm. ${ }^{8}$

Trata-se evidentemente de um preconceito, embora seja forçoso

\section{C. BARTHES, 1964. p.214-215.}

6. RAMOS, 1969. p. 10

7. BORGES, 1989. p.258. Nōo hovendo indentificoção, a troduçóo é sempre nosso

8. VALÉRY, 1993. p.7. reconhecer que tal fato ocorra com certa freqüência. Mas Borges, que foi ele próprio professor de literatura, procede à análise de textos, nessa mesma conferência em que defende a incomunicabilidade da experiência estética, por ele identificada com a poesia.

Se o fato estético é, como diz, algo tão evidente, tão imediato, tão indefinível como o amor, o sabor da fruta, a água, então o que ele quer identificar é a experiência estética com a experiência direta.

É sedutora tal relação, e aproxima-se mesmo do tema de minha última pesquisa, que trata do fato poético como estado diferenciado de consciência. Mas não se pode fazer identificações simplistas, pelo fato de a poesia se dar através da linguagem - lugar da dupla articulaçăo significante/ significado e, sobretudo, universo dicotomizado em sujeito/objeto enquanto a experiência direta prescinde da palavra e, mais do que isto, elide a diferença entre observador e observado.

O que se dá pela experiência direta é, no meu entender, a concepção da metáfora, razão pela qual Aristóteles observou que é a única coisa que não se pode ensinar, e é aí justamente que o poeta deve sobressair. ${ }^{9}$ Ele se referia ao processo criativo e, por conseguinte, à produção da metáfora - o que propicia a sua codificação, que, esta sim, se dá no universo lingüístico. Perceber a "analogia universal", como queria Baudelaire - é experimentar a diferença de uma maneira holística, o que pode parecer um paradoxo. Mas, de qualquer forma, não é com a nossa lógica que chegaremos lá.

É porque existe algo como a experiência direta que se diz que o poeta é aquele que mantém viva a criança no adulto, resguardando-a de um mundo estruturado pela aparência conceptual, do mesmo modo que se diz que o poeta nasce feito. O talento, o dom, ou que outro nome tenha, é da ordem do imponderável.

Quanto à decodificação, isto já é outra coisa. Partimos da linguagem e neste caso, sim, a experiência após a análise do texto pode tornar-se mais rica do que à primeira leitura. Porque se trata de experiência estética, fato cultural em função de um produto também cultural, que, embora fundado numa subjetividade não-discursiva, aquém da relação sujeito/objeto, pressupõe um entendimento racional.

Por todas estas questões, não deixa de ser incômoda a posição do

9. AR'STOTE, 1952 . 65: "Efetivomente, é o único coiso que nóo se pode receber dos outros; por esso mesmo rozōo, é sinol de tolento, isso porque bem empregor a metóforo é bem distinguir o que é semelhante." 
professor ao lidar com a poesia. É claro que deixar a leitura a cargo dos alunos, para que se dê de modo espontâneo a sua reação diante do texto, é o primeiro e imprescindível passo, para o que não se faz necessária, aliás, qualquer sala de aula. O trabalho analítico, entretanto, requer conhecimento, recursos teóricos - razão pela qual há disciplinas denominadas Teorias da Poesia - e nesse caso a orientação é fundamental, não no sentido de uma leitura dirigida que pretenda fechar "significados", mas que forneça os meios para a produção de sentido em função do texto. É evidente que a poesia compreende uma inesgotável fonte de procedimentos técnicos que instauram um código próprio não só com relação a cada poeta em particular, mas a cada novo poema. Entretanto, isto não impede que haja princípios comuns, mesmo em se tratando de linguagens tão diferentes, quanto a de nosso contexto cultural e a poesia do oriente. É o que se pode observar quando se cotejam características da linguagem poética formuladas a partir de uma fenomenologia de poemas nossos e as características apontadas, por exemplo, por François Cheng a propósito da poesia chinesa. Dentre os procedimentos passivos e ativos, por ele relacionados, muitos coincidem com traços do fazer poético de nossa cultura. ${ }^{10}$

Como observamos de início, a poesia não desperta grande interesse nos nossos currículos universitários, reflexo possivelmente dos pressupostos pós-modernos de que o poema é 'inanalisável', como qualquer obra de arte. "Entretanto, falando dos dispositivos de produção de subjetividade, Guattari observa que eles

podem existir em escala de megalópoles assim como em escala dos jogos de linguagem de um indivíduo. Para apreender os recursos íntimos dessa produção - essas rupturas de sentido autofundadoras de existência -, a poesia, atualmente, talvez tenha mais a nos ensinar do que as ciências econômicas, as ciências humanas e a psicanálise reunidas! 12

Enquanto isto, são muito prestigiados os estudos literários de natureza intertextual e os interdisciplinares, que se oferecem até mesmo em caráter obrigatório.

10. Cf. CHENG, $1977,30-45$

11. Cf. MONTAG, 1993. p.117

12. GUATTARI, 1992. p.33

\section{DA INTERTEXTUALIDADE}

Quanto às teorias do intertexto, mais do que prestígio, pode-se falar em sedução, não fosse a colagem a característica do discurso pósmoderno. $\mathrm{Na}$ literatura, na música ou nas artes plásticas e na arquitetura, o desconstrucionismo gera obras que se alimentam de outras obras, textos que vampirizam outros textos, de tal forma que esse entrelaçamento intertextual acaba tendo vida própria, tornando-se fim o que seria um meio. Mas se a colagem tem se tornado não apenas um recurso potencial, como sempre ocorreu na tradição literária, e sim um princípio estético de especial popularidade na arte contemporânea, os cursos universitários sobre literatura e intertextualidade estão fadados a esbarrar numa dificuldade básica: o limitado horizonte textual dos estudantes.

Por tudo aquilo que observamos quanto ao distanciamento da poesia relativamente aos interesses imediatistas de nossa cultura, o fato é que os poetas tornaram-se esquecidos. Apesar do grande número de poetas que há na Europa, e no Brasil, Badiou pergunta: quem conhece esses poetas? Quem os lê? Quem memoriza seus poemas?

De fato, há muito que a leitura deixou de ser uma prática não só individual, mas social no núcleo familiar. A arte da declamação, tão popular na minha infância, como também os teatros domésticos em que se fazia de tudo, animando os aniversários e os natais, foram inteiramente absorvidos pela tecnologia da comunicação, que, além da facilidade, oferece qualidade de nível profissional, ainda que discutível. E a falta de necessidade gera falta de hábito, refletindo-se, pois, na formação de uma cultura geral.

Para mostrar a importância de um tal substrato, lembro aqui que duas de minhas primeiras análises intertextuais, por exemplo, foram motivadas por reminiscências de infância que se tornaram fatores estruturantes das leituras realizadas.

É o caso do poema "Satélite"14, em que Manuel Bandeira chama o céu de plúmbeo:

\section{CF. BADIOU, 1994. p.75.}

14. Cf. RAMOS, 1969. p. 184-191. Este ensoio foi publicodo pela primeiro vez no Suplemento Literário do Correio do Monhõ. Rio de Joneiro, 17/10/1964. 
Fim de tarde.

No céu plúmbeo

a Lua baça

Paira

Muito cosmograficamente

Satélite.

Após o susto pelo mau gosto de um adjetivo tão literário e fora de época, uma outra lua começou a mostrar-se na minha memória nublada, até que brilhou de todo:

É noite. $\mathrm{O}$ astro saudoso

Rompe a custo um plúmbeo céu.

Além do plúmbeo, aí estão a circunstância de tempo - fím de tarde / noite - e o embaçado da lua:

Tolda-lhe o rosto formoso

Alvacento, úmido véu.

Como se vê de início, Bandeira não está parafraseando os versos de João de Lemos, mas dialogando com essa "Lua de Londres" na contraposição de uma outra -

\section{Desmetaforizada \\ Desmitificada \\ Despojada do velho segredo de melancolia.}

Como não era moda ainda essa abordagem crítica - aliás, nem a obra de Bakhtine tinha sido editada na Europa - pouco depois tive a satisfação de receber de Bandeira uma preciosa informação, a respeito de uma apropriação que não fora por mim reconhecida: nos versos

Nāo é agora o golfão de cismas

O astro dos loucos e dos enamorados

lêem-se os do "Plenilúnio", de Raimundo Correia.

Retomando a discussão sobre a experiência estética, creio que este exemplo ilustra bem o que eu disse a respeito do enriquecimento da experiência pelo background cultural. Pude observar muitas vezes que os alunos reagem de uma maneira muito mais intensa ao poema depois de conhecerem o jogo intertextual levado a efeito pelo poeta, do que à primeira leitura. E, sem dúvida alguma, o entusiasmo seria ainda maior se em vez de um conhecimento desse jogo, eles tivessem, de modo espontâneo, experimentado um reconhecimento.

Num outro texto, em que se contrapõe igualmente o mundo de hoje ao de ontem, observei que Drummond dialogava com poetas do passado, através de versos adormecidos no meu remoto repertório de declamadora ${ }^{15}$. O poema de Drummond tem o mesmo título que um de Fagundes Varela - "Anoitecer". Enquanto ele diz -

É a hora em que o sino toca

Mas aqui não há sinos,

o sino de Varela se faz ouvir logo na primeira estrofe:

$\mathrm{Na}$ torre estreita do pobre templo

Ressoa o sino da freguesia.

Do mesmo modo, quando lembra -

É a hora em que o pássaro volta mas de há muito não há pássaros -

levantam vôo as pombas de Raimundo Correia, ao soprar da rígida nortada:

Ruflando as asas, sacudindo as penas

Voltam todas em bando e em revoada.

Finalmente, os versos -

É a hora do descanso

mas o descanso vem tarde -

evocam os de Francisca Júlia:

Desmaia a tarde. Além, pouco a pouco, no poente,

O sol, rei fatigado, em seu leito adormece.

Aliás, nesse soneto estão também os pássaros que se recolhem e os sinos plangentes - motivos então imprescindiveis a um poético 15. Idem. 1985. p. 213-226. Esse ortigo foi publicado primeiromente no Suplemento Literório de 0 Estodo de São Poulo, Säo
Poulo,21/3/70 
anoitecer:

Uma ave canta, ao longe; o ar pesado estremece

Do Ângelus ao soluço agoniado e plangente.

O poema de Drummond, entretanto, contrapõe a esse quadro bucólico a hora do rush, em que o homem massificado da sociedade industrial deixa a fábrica para escorrer na multidão em busca de uma paz que é "morte, mergulho / no poço mais ermo e quedo."

$O$ trato constante com a poesia; a intimidade com a ficção narrativa, que desde cedo abrangia não só os nossos autores, mas traduções de obras como o Dom Quixote; o trânsito pelo drama, pelas escrituras independentemente de um propósito religioso - e, a partir do período acadêmico, o convívio com a antigüidade proporcionado pelo meu curso de Letras Clássicas; a descoberta dos ensaios de crítica literária e da filosofia, tudo isto constituiu na minha formação um chão discursivo em que se tecem as relações intertextuais.

Foi assim que pude apresentar, em 59, uma comunicação ao $\mathrm{IV}^{\circ}$ Colóquio Internacional de Estudos Luso-Brasileiros, mostrando como Cecília Meireles se apropriara do Romance del Prisionero - um dos mais populares da Península Ibérica - para escrever os seus próprios romances relacionados com Tomás Antônio Gonzaga, a figura mais romântica da Inconfidência. ${ }^{16}$

Enquanto lá se dizia -

Que por mayo era por mayo,

cuando hace la calor

cuando los trigos encañan

y están los campos en flor,

cuando canta la calandria

y responde el ruiseñor -

Cecília começava assim o Romance "Do enxoval interrompido":

Em Maio, era em Maio,

num Maio fatal.

Mais adiante, a inversão do texto:

16. Idem, 1960. p.43-67
Era em Maio, foi em Maio,

sem calhandra ou rouxinol,

quando se acaba nos campos

da roxa quaresma a cor.

Do mesmo modo, em Amar, verbo intransitivo, li o Banquete, de Platão, que Mário de Andrade retomou não apenas no título de seu romance, mas no próprio argumento, inspirado no discurso de Sócrates. A governanta alemã contratada, entre outras funções, para proceder à iniciação sexual do adolescente, é uma versão capitalista da sacerdotisa Diotima, que o filósofo celebra como a sua mestra em coisas de amor. Também nesse texto me foi possível reconhecer uma prática expressionista, que acompanha de perto a enumeração de princípios teóricos inserida no romance como uma colagem explícita — um Manifesto - a pretexto da história. ${ }^{17}$

Outras análises intertextuais revelam aspectos até mesmo surpreendentes, como por exemplo "Leitura/escritura em Maira, de Darcy Ribeiro"18, romance em que o Autor, cujo pensamento é notoriamente marxista, faz uma montagem de discursos religiosos, como a Missa, o Antigo Testamento e São João da Cruz, juntamente com Nietzsche, Althusser, Lacan, Drummond e outros mais.

Embora a missa tenha tido a função de estruturar os capítulos nos moldes da liturgia, o texto básico com o qual Darcy estabeleceu o seu diálogo foi o Livro de Isaías, cuja profecia foi invertida em função do contexto.

Há no romance uma referência expressa a esse texto, não só pelo nome da personagem, mas pela função que exerce entre as duas culturas - o mundo civilizado e a sociedade indígena. Isaías é o mediador ${ }^{19}$, o indiozinho que os missionários criaram, educaram e enviaram a Roma para coroar o seu trabalho. Entretanto, às vésperas de receber ordens, ele experimenta o conflito de, sendo Isaías, não agir como o profeta, que teve

77 Idem, 1979. p.76-103. Esse texto constituiu comunicoşão apresentoda ao IV Congresso Nacional de Estudos de Lingüística Literotura, promovido pelo Sociedade Universitório Augusto Moto, com o fítulo "A linguagem onírico no narrotivo de ficcóo." Rio de Janeiro, 1978

18. Idem. 1985, 149-177. Esse ensaio foi publicodo no Suplemento Culturol do Estado de São Paulo em 19/3/1978 e opresentodo ao Illp Congresso Nacional de Estudos de Lingüístico e literaturo promovido pela Sociedade Universitúrio Augusto Moto. Rio de
Janeiro, 1977 .

19. É surpreendente que dois livros tão diferentes, como o Antigo e o Novo Testomento, constituam os fundamentos de uma só

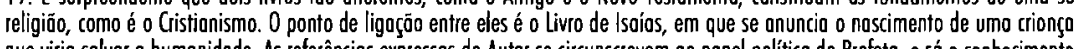
que virio solvar a humanidode. As referênncios expresssas do Autor se circunscreveem oo popel político do Profeto, e só o conhecimento

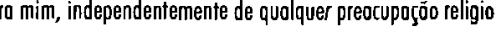
- possibilitou o reconhecimento do inversâa nietzscheono. 
a palavra purificada pelo fogo a fim de conscientizar o seu povo da opressão estrangeira. Ordenando-se, ele se tornaria o anti-Isaías, o que acabou por levá-lo de volta à aldeia. Fracassa, porém, ao querer ocupar o papel que lhe cabia à frente da tribo, porque, vivendo num mundo capitalista e estando já condicionado pela ideologia cristã, ao invés de assumir o seu povo criticao e age de maneira a transformá-lo. A inversão da profecfia bíblica — os gêmeos gerados por Micura nascem mortos, sendo portanto mais filhos de Nietzsche do que desse deus - é apenas um dos aspectos importantes desse livro, cuja riqueza se mostra ainda nos ritos de passagem; na problemática da tradução que se depreende do trabalho de Isaías com o Evangelho de São Mateus; na escritura do trabalho artesanal; no papel de Alma - personagem-especular de Isaías; na afinidade de significantes que se verifica nos nomes das personagens principais - Anacã, Alma, Avá, Jaguar, e, sobretudo, Maíra e Isaías, que contêm a mesma seqüência $a-\hat{i}$ presente no nome do Autor - Darcy - que se torna metapersonagem da história; na contradição do próprio sujeito da enunciação, expressa através dessas duas personagens - o deus e o fraco - e em tantos outros, que não cabe aqui relacionar. Mas a contradição fundamental está no fato de que, se a personagem fracassa na missão de conscientizar o seu povo (disselhe o Senhor: "Toma um grande volume e escreve nele em estilo de homem: "Apressando-se ao despojo, apressurou-se à presa.") o Autor dela se incumbe, ao escrever o romance. A enunciação resgata, pois, o enunciado.

Também em "O beijo inconsútil" ${ }^{20}$, ensaio que escrevi sobre $O$ Guarani, de Alencar, mostrei como se estrutura a narrativa em função do mito de Tamandaré, de um livro de hagiografia, em que se narra a vida de Santa Cecília, e versos portugueses que falam do amor impossível entre um mouro e uma cristã.

\section{Mas, certamente,}

é vão tentar dominar um texto, porque o perpétuo entretecer de textos e sentidos está fora do nosso controle; a linguagem opera através de nós?

Assim, o passeio que fizemos ao longo dessas obras constitui outros textos - uma colagem que pode ser substituída por outras, na medida em que novas leituras se interponham, como novas referências,

20. Idem, 1983. p. $113-132$

21. HARVEY, 1994. p.54 entre o livro e o leitor. De qualquer modo, o essencial é que haja leituras.

Mas infelizmente lê-se muito pouco hoje em dia, refletindo-se este fato no empobrecimento da memória cultural. É verdade que outras formas de expressão, como o cinema e o video, com seus recursos multimidia, tendem a alargar esse horizonte. De uma maneira relativa, porém, porque esses recursos são aquisições muito recentes, enquanto a literatura abarca séculos de produção ininterrupta. Assim, se os textos não se armazenam de uma maneira significativa na memória, de onde possam afluir ao menor estímulo fornecido pela leitura, é ao professor que cabe apontar a sua interlocução, ficando, portanto, o estudante sujeito a ver sempre através de olhos alheios. Tal procedimento imprime um caráter passivo ao trabalho acadêmico, contrariando as tendências contemporâneas de criatividade através do entrelaçamento textual, e desvirtuando os próprios objetivos dos estudos universitários.

\section{DA INTERDISCIPLINARIDADE}

O mesmo se verifica nos cursos interdisciplinares, uma vez que as disciplinas com as quais se vão confrontar os estudos literários são específicas de outras áreas das ciências humanas. Nesse trabalho, a condição fundamental para que seja levado a efeito com sucesso é obviamente conhecimento das disciplinas em questão. Mas é no próprio espaço das Letras que os estudantes vão receber esse conhecimento, mediatizado pelos professores que devem, eles próprios, adquiri-los por iniciativa própria independentemente de uma formação sistemática. E se esses mestres desenvolvem um árduo, ainda que prazeroso, trabalho esses mestres desenvolvem um arduo, ainda que prazeroso, trabalho autodidata, cujo mérito vai refletir-se $\mathrm{cm}$ suas pesquisas e ensinamentos, o mesmo interesse não se pode esperar dos estudantes, nem similar aproveitamento, principalmente porque se defrontam com disciplinas diversas dentro de uma mesma disciplina - Literatura e Interdisciplinaridade - as quais lhes consomem o tempo. O que forçosamente acontece é terem eles uma informação fragmentada - o que poderá, é claro, levá-los a um posterior aprofundamento igualmente positivo desses estudos - mas conhecimento que na maioria dos casos fica prejudicado pelo caráter disperso com que é trazido de outras áreas. Predomina também aí uma forma de colagem cultural, certamente ao gosto da época, mas cujas conseqüências não se podem prever. 
Outra dificuldade dos estudos interdisciplinares é que nem sempre é fácil fazer-se um recorte dos aspectos mais pertinentes às questōes literárias, sem que as lacunas provoquem distorções. No caso de essa interlocução se dar com a psicanálise, a situação é ainda mais complexa, pois além do conhecimento teórico é preciso que o pesquisador tenha se submetido, ele próprio, a um processo analítico, certamente desejável, também, aos que vão lidar com esse tipo de reflexões.

Assim, a formação em outras áreas que não os estudos literários fica sujeita às circunstâncias da história pessoal de cada um: gosto por determinada matéria, cumprimento de compromissos acadêmicos, acesso à bibliografia, oportunidades de estudo orientado, ainda que fora de programaçōes curriculares.

No início da minha carreira universitária, por exemplo, não havia sido ainda instituído em nossa Universidade o curso de Psicologia. Mas uma intensiva leitura nessa área ${ }^{22}$ fez com que eu me interessasse pela crítica psicológica, trabalho que desenvolvi a meu modo numa tese acadêmica, orientando-me também por um procedimento que se chamou então de "crítica integral" e se propunha levar em conta os aspectos intrínsecos e extrínsecos do texto literário. ${ }^{23}$

Em 61, por ter assumido a regência da disciplina Teoria da Literatura, que então se instituía no currículo, concentrei-me na obra de Roman Ingarden ${ }^{24}$, que fundamentava a análise do texto na fenomenologia de Husserl. Essa abordagem surgia como a forma mais promissora de tratar a estrutura da obra literária, segundo o ideal de objetividade reclamado pela crítica, numa época em que se dava uma reação contra o historicismo, por um lado, e o impressionismo, por outro, reivindicando-se critérios científicos para a atividade crítica. Tais critérios se credenciavam como método na obra de Ingarden, o qual desenvolvi em função de minha própria experiência, na caracterização da estrutura polifônica do texto através da

22. Circunstôncios relativas a um concurso público em que hovio umo provo de Psicologio e Pedagogio orientodas paro o adalescente me levaram 0 umo leitura intensiva que ocabou por me instigor a submeter-me entōo a um processo de análise, ainda que so a meio voz se folasse então em psicoteropio. Meses depois o teropeuto me propôs urma onólise didática, que devio preporar-me poro o atendimento de crionços e adolescentes em uma dínica que ele pretendio criar. Além de obras básicas de Freud, li sob suo orientoçóo, textos de Koreen Horn, Adler, Steckel, Otto Rank, Mergareth Mead e sobretudo Melanie Klein — isto na década de cinquenta, quondo entre nós aindo näo se divulgovo a revvlorizoção da teorio freudiona, feita por Lacan. Ero uma perspectivo sedutora que se abria, mos que se frustrou pelo foto de ele ter-se mudado poro o Rio de Janeiro, onde se rodicou. Somente anos mais torde é que recorri de novo ò onálise.

23. RAMOS. 1957. Com esso tese, obtive o título de Livre-Docente em Literatura Brosileira no Foculdade de Filosofia da Universidade de Minos Gerois, depois Foculdade de Letras do UFMG.

24. INGARDEN. 1960. A obra foi editoda em Lisboo pelo Colouste Bulbenkian em 1973, em troduçäo de Albiu E. Beau, Maria do Conceiçōo Pujo e Joōo F. Barrento. especificidade de seus fatores constituintes. Mas para isto tive de voltarme para a filosofia, a fim de fundamentar os estudos nessa área.

Interessei-me depois pelo mito, que tive oportunidade de estudar em curso feito nos Estados Unidos (1972) com uma bibliografia formada pela obra de antropólogos e etnólogos de diferentes formações científicas, enquanto no Brasil o estruturalismo centralizava esses estudos. Ali também segui cursos de Literatura Comparada, que me abriram novas perspectivas, sobretudo no que respeita a uma reformulação do conceito de tradução. ${ }^{25}$

Por variadas que sejam, entretanto, essas abordagens do texto, não foram elas levadas a efeito simultaneamente. $E$ o que tem marcado o meu trabalho, e lhe confere coerência, é sobretudo o interesse pelo conhecimento do humano, propiciado pela via real da literatura. Assim, na psicologia seduziu-me a psicanálise, em função sobretudo da complexidade da constituição do sujeito; na fenomenologia, a recursividade do percurso entre o sensível e o eidético; no mito, a concomitância da universalidade da célula mítica com a singularidade do texto literário.

De qualquer forma, seja na poesia, no drama ou na fiç̧ão, é nas obras literárias que se encontram os fundamentos de princípios desenvolvidos mais tarde pelo tratamento científico da natureza humana, nas vicissitudes da relação do sujeito com o mundo. Esse conhecimento intuitivo do artista tem-se antecipado, por exemplo, à psicanálise, que veio enriquecê-lo com o corte epistemológico constituído pela descoberta do inconsciente. Daí o fato de os estudos psicanalíticos merecerem, na minha atividade intelectual, uma permanente dedicação.

\section{LITERATURA E PSICANÁLISE}

\section{INTERLOCUÇÃO}

Na gama de disciplinas que freqüentemente fazem interlocução com os estudos literários escolhi, pois, a psicanálise para fazer aqui algumas reflexōes sobre os processos de sua aplicabilidade.

25. 0 efeito mulfiplicador desso experiêncio se concretizou em ensoios e disciplinas que ministrei no Curso de Mestrodo de nosso

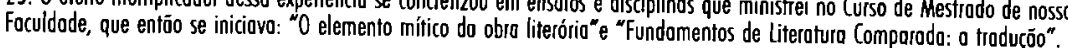


A relação entre essas áreas do conhecimento vem se tornando tão estreita, que se deixa ver até em situações aparentemente sem importância, como a distribuição dos livros nas prateleiras das livrarias e de bibliotecas. Os que procuram títulos de uma disciplina encontram à mão os relativos à outra, colocados lado a lado para facilitar a consulta. Também os estudos lingüísticos aí costumam ser encontrados, e logo a filosofia, a antropologia, a semiótica, enfim, toda uma intrincada rede de ciências humanas.

A particularidade de nosso trabalho é a mediação de um texto, fato que já interfere na relação analítica, baseada no processo de transferência. Freud, entretanto, diagnosticou a psicose de Schreber através de seus escritos, sem nunca ter tido com ele um contato pessoal, o que relativiza o papel da transferência como condição sine qua non do processo analítico. ${ }^{26}$ Mas não é pela via do diagnóstico que se processa em nosso meio a pesquisa de psicanálise aplicada à literatura.

Esta visa ao texto. E ao falar em texto, temos de distinguir de início entre o ato de escrever, testemunho de um determinado estado mental, como no caso Schreber, cuja enunciação é direta, e a escritura literária, que, sendo uma produção estética, pressupõe uma elaboração sofisticada, ou, em outros termos, uma relação dialética entre o dionisíaco e o apolíneo. Assim, a personagem que se enuncia o faz pela mediação de uma outra enunciação: a do autor do texto. ${ }^{27}$

Ocupando-se ambas da natureza humana, psicanálise e literatura interagem de modo tão estreito, que é natural que as pesquisas nessa área se revistam de características diversas, orientando-se por princípios distintos, ainda que numa linha comum. É o que se depreende das publicações que se têm feito no âmbito mesmo de nossa Universidade, atestando o interesse por essa abordagem e o leque de possibilidades que oferece ao pesquisador.

A relação da psicanálise com os estudos literários mostra-se, por exemplo, através do trânsito de conceitos vários, desde a constituição do

26. Cf. OLIVEIRA, 1994. p.II2: "A clínico psiconalíitco nõo é uma clínico descritiva, nem fenomenolágico, mos é umo dínica estruturol, na medido em que o dignóstico se estobelece no transferênncio. 0 que nóo quer dizer que o diagnóstico sejo sobre o transferêñcio, consideranda a tronsferêncio que ele organizo, como un fenâmeno a mais. (...) Freud abriu um precedente com 0 cosa Schreber, cujo diognóstico foi formulado otrovés de suas memórios." Concluindo, o Autor se permite "uma fantosia"- - a de considerar Tita nōo como personagem do romance de Louro Esquivel, mas como uma cliente que the batesse à porto, umo vez que

27. Cf. RAMOS, 1981. p.129-149: "Odisseu, Dom Quixote e Riobolda, pela sua natureza de personogens, sä́a existencialmente condicionodos por um rexto. Vivem no discurso, sendo o seu universo caracterizado por um determinado enunciado. Como personogens são, portanto, resultontes de umo enunciagsóo, produçoo de um outor que, por sua vez, é um produto social, o que nãa subentend uma concep̧̧̄óa determinista " sujeito contida no registro freudiano, em cujo contexto se dá o revolucionário enfoque da linguagem caracterizado pela "química silábica", até o desenvolvimento desses princípios pela leitura participante e criativa de Lacan, que faz dessa química o ponto capital de seus estudos, ao mostrar que o inconsciente se estrutura como uma linguagem e o sentido se produz na cadeia do significante.

Para explicar os mecanismos do sonho, Freud se vale de palavras de Schiller relativas ao fazer poético, palavras que mais parecem pertencer ao seu próprio discurso:

Encarado isoladamente, um pensamento pode parecer muito trivial ou muito fantástico, mas pode ser tornado importante por outro pensamento que venha depois dele, e, em conjunção com outros pensamentos que possam parecer igualmente absurdos, poderá vir a formar um elo muito eficaz.

E Lacan, lembrando que Freud considera a qualificação literária como principal requisito para a formação de analistas, acrescenta que a emergência do sentido se dá na substituição de um significante por outro significante, sendo esse processo relativo a "um efeito de significação que é de poesia ou de criação." 29 Nesse mesmo ensaio chama a atenção para a escuta da poesia,

para que se faça aí escutar uma polifonia e para que se reconheça que todo discurso se alinha sobre as diversas pautas de uma partitura. ${ }^{30}$

E dentre outros exemplos, gostaria de lembrar ainda o seu comentário a respeito do famoso chiste "familionário", analisado por Freud: "ato falho ou criação poética?"3

É princípio básico da psicanálise, que esta se processe através da fala. A oralidade garante o fluxo do logos, que propicia a expressão do sujeito. Uma vez pronunciada, a palavra não pode reverter-se, a não ser pela correção - no lapso, por exemplo - o que ao invés de negá-la a reafirma.

Mas o que tenho procurado mostrar é que não são apenas o sonho e a fala o lugar das formações do inconsciente. Também o texto literário,

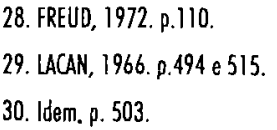

31. Idem, 1979. p.72 
malgrado a sua condição de palavra escrita, subalterna perante o logos, como foi apontado por Platão e ratificado por Derrida - pode abrigar tais formações. ${ }^{32}$

A leitura psicanalítica de um texto não se atém, pois, a interpretações via significado, o qual, na sua natureza de conceito, é uma construção mental, de resto, imponderável. O significado, como o diabo de Guimarães Rosa, não existe como cidadão. Um insiste na cadeia do significante, o outro vige no homem - os crespos do homem, ou o homem dos avessos. ${ }^{33}$

Se nos lembrarmos de que a condensação é da ordem da metáfora, então é lícito pensar que ela se dá por experiência direta, codificando-se então mediante a elaboração metonímica do significante, que já constitui uma operação racional. E como esta é a única de que dispomos no processo de decodificação, é por aí que temos de iniciar o nosso trabalho. Detenhamo-nos, portanto, no fato concreto que é o deslocamento - a materialidade do significante, o in praesentia metonímico que propicia a operação metafórica in absentia. ${ }^{34}$

Minimalista avant la lettre, a redução na Teoria da Literatura de mais de duas centenas de figuras de linguagem e tropos a apenas esses dois procedimentos - metonímico e metafórico - tem a ver também com o discurso psicanalítico, que parte da formulação dos processos primários - o deslocamento e a condensação.

\section{PROCEDIMENTOS ONÍRICOS}

Se o texto literário é também vetor das formações do inconsciente, é possível, pois, detectar nele os procedimentos oníricos, por exemplo, que, sob a forma de um disfarce, tornam manifesto aquilo que foi reprimido. E não é o reprimido - como significado - que importa elucidar, e sim a maneira como se estrutura a narrativa. Assim, determinadas interpolações, que muitas vezes são consideradas como enxertos no texto, que o retardam e desviam a atenção do leitor, provocando quebra de interesse pela leitura, se consideradas de uma outra perspectiva resultam

\section{Cf. PLATÄ0, 1950. p.13 e segs. e DERRIDA, 1968. p.3 e segs.}

33. RAMOS, 1990. p.8.

34. Idem. 1984. p.179 e segs. ser o prosseguimento da narrativa, mas cifrada em outro código, em que flui a mensagem ao nível do desejo.

Mas quando, em determinada passagem de uma narrativa, se pode falar que houve qualquer coisa assim como um sonho? Em primeiro lugar, é preciso considerar o contexto, onde se tramam os pensamentos oníricos. E fundamental é o corte no discurso - significante do deslocamento; a transposição para outro código; a condensação entre a situação anterior ao corte e o que se enuncia após este, o que se dá, freqüentemente, por um lapso.

Em Amar, verbo intransitivo, por exemplo, romance que motivou uma das minhas primeiras análises nesse sentido, ${ }^{35} \mathrm{o}$ envolvimento entre Carlos e Fräulein Elza vai se intensificando até chegar ao clímax em que deveria ocorrer a relação sexual. No momento do encontro, entretanto, o Narrador observa:

Porém obedeço a várias razões que obrigam-me a não contar a cena do quarto. ${ }^{36}$

Inicia-se então uma longa interpolação, em que o Narrador se interroga sobre as relações da governanta com o criado japonês: "Inimigos?" E logo, aludindo a um poema de Castro Alves, sugestivamente intitulado "A Queimada", descreve o incêndio que

galopa destruindo matos, sacudindo as trombas curtas de fogo no ar.

Dentre os animais desse habitat, diz o Narrador que inimigos não são a corça e o tigre, como figuram no poema:

Mais inimigos ainda, mais muito mais! são o tigre e o tigre. Agora sim, a metáfora pode convir.

Os quadros que se seguem são descritos com grande pompa retórica, num estilo diametralmente oposto à linguagem coloquial em que se desenrola o romance. $\mathrm{Na}$ queimada

"que esbraveja em torno", "os dois tigres vão trêmulos se unir"; "as labaredas lambem a rocha"; "O repuxo das fagulhas dançarinas vidrilha de ouro o fumo lancetado pelas cuquiabas dos quaribas. Os

\section{Cf.RAMOS, 1979.}

36. ANDRADE, s/d. 90 e segs. 
dois tigres ofegam. Falta de ar. Sufocam, meu Deus!"; "os dois tigres acabarăo por desaparecer assimilados."

Toda essa interpolação, de que extraí apenas algumas passagens, não é senão o conteúdo manifesto do deslocamento da cena do quarto para o incêndio, em que os protagonistas se metaforizam nos tigres e o ato sexual na luta. Aliás, um traço característico de Carlos, ao longo da narrativa, é a sua agressividade, observando muitas vezes o Narrador que ele vivia a machucar a irmã, até que conclui:

E determinei bem que ele era um machucador de marca maior.

Mas é ao retomar a narrativa interrompida que o Narrador se trai e estabelece o vínculo entre as duas cenas, condensando-as:

Carlos sai cuidadoso do quarto de Fräulein. Caminha na maciota. Todo cuidado é pouco, năo? com pés de onça ele pisa.

Onça, então, surge agora como significante, atestando a condensação - ou a metáfora - que envolve o rapaz e o tigre. Quanto à Fräulein, essa o Narrador já havia dito que não poderia ser a corça, pois “a comparação tomava assim uns ares de pureza". Ela era, portanto, o outro tigre. Os demais elementos do "sonho" são irrelevantes. Freud chamou a atenção para o fato de que

o que devemos tomar como objeto de nossa atenção não é o sonho como um todo, mas as parcelas isoladas de seu conteúdo. ${ }^{37}$

Assim, o criado japonês, na sua qualidade de "inimigo", serviu de ponte para o questionamento de quais seriam os verdadeiros inimigos no "incêndio" da interpolação.

Em outra oportunidade analisei de maneira minuciosa essa passagem do romance, o que não cabe repetir aqui. Torna-se evidente, porém, que o Narrador, dizendo que não ia narrar a cena do quarto, acaba narrando-a, mas através de uma atualização fantasmática. A "interpolação" deixa, pois, de ser uma excrescência de efeito negativo quanto à construção do texto, para revelar-se como elemento estrutural deste.

De modo geral, percebe-se a ação do inconsciente quando a lógica do discurso fica comprometida. É claro que se trata de uma lógica do texto,

37. FREUD, 1972. p.111. por ele instaurada - uma lógica ficcional, neste caso do romance de Mário de Andrade. Chamou-me a atenção o fato de o Narrador ter dito que o adolescente adormecera sentado aos pés da cama, enquanto aguardava a meia-noite para ir ao quarto da governanta. Ora, esse seria o primeiro encontro, proibido, ansiosamente esperado numa relação cotidiana cheia de estímulos sexuais, o que torna a cena inverossímil: exatamente um dormir no ponto. Acordou com meia hora de atraso e, apesar da necessidade de não fazer qualquer barulho na casa silenciosa, esmurrou a porta - o que permite, aliás, duas leituras, pois já se sabe que ele é "um machucador":

Bate. Bate forte, com risco de acordar os outros, bate até a porta se abrir, entra.

Depois disso, como vimos, o Narrador alega obedecer a várias razões - que não declara - para não contar o que ali se passa, interrompendo a história para falar de "outra coisa".

Um romance em que demostrei, igualmente, que as interpolações funcionam como conteúdo manifesto de um discurso liberador de componentes fantasmáticos, é Vila dos Confins, de Mário Palmério. ${ }^{38}$ Do mesmo modo que no caso anterior, não é o significado desse conteúdo que importa, mas a sintaxe narrativa. Também aí um encontro é iminente: o de Paulo - político que viajava em campanha pelo interior - e Maria da Penha, filha do dono da fazenda em que ele se hospedara, para convalecer de uma malária. Depois de vários assédios por parte da mulher, cujas referências são sempre ligadas ao perigo e mesmo à suspeita de haver matado o marido enquanto este dormia, decide ir ter com ela. A noite é de lua cheia e ele segue enfeitiçado. Já tinha avistado a parte superior de seu corpo na janela, quando a narrativa é cortada por um grito:

Berro que não parava, acomprido, agoniado, terrível. Só uma vez, em menino, Paulo ouvira coisa igual: fora na fazenda, quando assistia à castração da garrotada de corte...

Passa a contar, então, o que ocorrera: um boi, cego de um olho, dirigira-se ao rio para beber água e foi devorado por uma sucuri -

o pior dos destinos: acabar em boca de sucuri... boca em ventosa chupão maldito que nada amortece, a que nada resiste, vindo das profundas de cinqüenta palmos de esfomeação.

38. Cf. Idem, 1975.

39. PALMÉRIO, 1956. p.154 e segs. 
Com requintes de detalhes, narra as suas artes de "espichaencolhe", até que o boi vira "um bagaço". Recapitulando: o deslocamento se deve a um grito, associado a uma lembrança da infância relativa à castração de garrotes; a sucuri, como metáfora da mulher, "não era de agora que vinha vigiando a rês"; Do mesmo modo que ela, tocaiava a presa - "de fora da água, só a cabeça"; o boi, alquebrado e cego de um olho, metaforiza o homem, convalecente e cegado pelo desejo.

Como na época eu estava trabalhando com a infra-estrutura mítica do texto literário, essa interpolação, de tipo onírico, interessava ainda como uma variante dos mitos da mulher devoradora - um exemplo entre outros que Roger Caillois recolheu ao tratar do inconsciente coletivo na função do mito. ${ }^{40}$ Assim também como no caso anterior, um lapso estabelece o vínculo entre as duas situações: a dos pensamentos oníricos e a do sonho. Dizendo que na manhã seguinte a moça aparecera com seu jeito atencioso de sempre, observa:

As olheiras escuras contavam, porém, da desilusão da noite fracassada.

Essas olheiras escuras constituem, pois, um significante relativamente à noite que, ao invés de ter sido fracassada, fora-lhe bem sucedida. Mas não é tudo: no final do romance, quando Paulo se encontra já praticamente vitorioso nas eleições, volta a encontrar Maria da Penha, que tinha ido à cidade para votar. Novamente ela o assedia e ele se entusiasma com a perspectiva do encontro. E novamente o que se narra é um zebu, que assustado pelos foguetes, salta da balsa para o rio, onde é devorado pelas piranhas.

\section{LINGÜISTERIA}

Ao estruturar-se um texto literário, a produção de sentido pode dar-se também de modo sui generis na cadeia do significante, dissociandose de maneira ainda mais surpreendente o que é dito daquilo que não se sabe que está sendo dito: "où çà parle, f̧à jouit, et çà sait rien"»l - já observou

40. Cf. CAlLOIS, 1972. p. 35-83. Nesse capitulo o Autor referer-se ao comportomento sexuol da lêmea do louvo-deus - em Tancês la mantereligieuse - que devoro o macho duronte a cópula, o que fundomentrasio o "mito da vogino dentada", considerado francês la monte-religieuse - que devoro o mo mocho duoto dos mitos relotivas ò costroçó.

41. LACAN. 1975. 20: Onde isso fala, isso gozo, e de nodo sobe. Lembre-se que hó em francês umo ombigüidode que se perde no

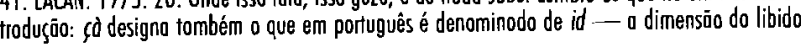

Lacan. Neste caso não há necessidade de cortes, nem de "interpolações" o que costuma ocorrer na prosa narrativa - pois é na relação significante/ significado que um outro discurso se manifesta - um discurso subversivo cujo código se estabelece nà afinidade de sons entre uma palavra e outra, ou seja, na cadeia do significante.

Vejamos como se processa tal subversão do sentido manifesto, nessa vampirização de um texto por outro.

Como no caso anterior, são pequenos indícios que traem a dupla articulação: o emprego de um possessivo, por exemplo, inserindo na cena o sujeito da enunciaçâo, e maiúsculas inesperadas, me levaram a uma associação que logo se ratificou com novos dados ao longo do texto. Tratase de Le cimétière marin ${ }^{42}$ - poema considerado como dos mais herméticos de Valéry - o que já é indício de uma torturada expressão. Aliás, das vinte e quatro estrofes, consta que apenas duas permaneceram inalteradas em meio a inúmeras modificações operadas no texto pelo Poeta. ${ }^{43}$

A semelhança entre os sons - qualidade do significante - faz com que o significado barrado de um determinado signo se refugie num outro signo cujo significado, por sua vez, nada tem a ver com o primeiro, enquanto o significante é idêntico, ou afim. ${ }^{44}$ Estabelece-se, pois, uma cadeia, cuja leitura não é da ordem da lingüística, mas de um registro que Lacan chamou de lingüisteria ${ }^{45}$ - o espaço não da língua, sistema socialmente codificado, mas de lalangue, que obedece a um código pessoal, relação materna por excelência.

Assim, o poema se inicia com uma evocação do telhado - ce toit tranquiille - em que passeiam as pombas, e que palpita entre as tumbas les tombes. Palpitar já é uma animização para esse telhado, do mesmo modo que mais adiante se humaniza o mar: La mer fidèle $y$ dort sur mes tombeaux! A passagem da animização - "dorme" - à humanização - "fiel" - é o agente da transformação de les tombes em mes tombeaux. São palavras sinônimas, que se alternam nos dicionários. Mas é aí também que se registra para tombeau um outro sentido - lit en tombeaux - que, referindo-se a um leito acortinado, conota o berço. Está formado, portanto, o campo semântico onde mer e mère se confundem — uma mãe fiel junto ao berço

\section{VALÉRY, 1957. Apud RAMOS, 1985. p.202-223}

43. CF. WANDERLEY, 1984.

44. C. LACAN, 1966. 515.

45. Idem, 1975. p.20.
REVISTA DE ESTUDOS DE LTERATURA
Belo Horizonte, v. 2, p. $09-50$, out. 94 
do filho. A partir daí, toit já não é mais o telhado, mas toi - tu - que merece uma maiúscula quando, na terceira estrofe, o Poeta exclama neste vocativo:

O mon silence!...Édifice dans l’âme,

Mais comble d'or aux mille tuiles, Toit!

A condensação está feita, mediante a afinidade dos significantes, sendo que a relação mer/mère chega a ser um lugar comum na literatura psicanalítica. Quanto aos outros termos, é bom lembrar o que disse Freud a respeito da química silábica:

Pode parecer estranho que a elaboração onírica faça um uso tão livre da ambigüidade verbal, mas outras experiências nos ensinaram que a ocorrência é bastante comum. ${ }^{46}$

O mesmo vale para os chistes, os lapsos e toda elaboração relativa às formações do inconsciente. $\mathrm{E}$ não é só a figura da mãe que aparece assim metamorfoseada no poema. Também a imagem paterna surge logo no verso seguinte, sob a forma de Midi le juste, um Midi là-haut, que En soi se pense et convient à soi-même. Mais uma vez não se trata de uma associação de idéias, via significado, mas uma relação de significantes, que faz de Midi aquele que $M e$ dit, ou seja, a metáfora paterna, portadora da palavra e da lei.

Interessante é que o hermetismo, a que já me referi, cede lugar a um discurso coerente, quando considerado o poema desde esse registro da lingüisteria. E para tornar mais clara esta análise, apenas mais um exemplo. Na estrofe 22, o verso Une frâtcheur, de la mer exhalée - torna a mãe tão presente, que a sua fresca carne - fraîche chair - que aí repercute, vai ressurgir logo adiante na imagem Peau de panthère, expressão que faz deslisar a pele sobre a chair bleue - a carne azul, que afinal se explicita ${ }^{47} \mathrm{e}$ da qual o vento se embriaga.

46. FREUD, 1972. Vol. V, 0.690 .

47. Apud RAMOS. 1985. p. 211 :

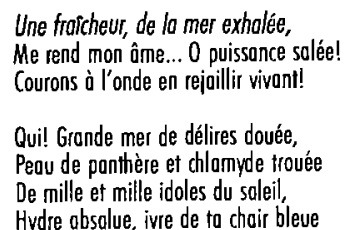

Une froicheur, de lo mer exholée, Me rend mon îme... 0 puissance solé De mille ef mille idoles du saleil,

Hydre absolue, ivre de ta choir bleve
É claro que se deve a Freud o tratamento da linguagem a partir da "química silábica", mas Valéry mesmo teve intuições muito próximas, quando observou, por exemplo:

As propriedades sensiveis da linguagem têm também uma relação importante com a memória. Há palavras que têm muita afinidade com o suporte misterioso da recordação: cada uma parece ser afetada por uma probabilidade particular de restituição exata, que depende da sua figura fonética. ${ }^{40}$

Como vimos de início, a relação literatura/psicanálise se mostra através do trânsito de conceitos, não só no que se refere à sua aplicabilidade, mas também na sua própria formulação. E foi ainda Valéry que disse encontrar um homem muito antigo em todo verdadeiro poeta:

ele bebe ainda nas fontes da linguagem..$^{49}$

Certo que é a um ponto de vista antropológico que se deve tal observação. Mas ao finalizar esse ensaio, após minuciosa análise em que desvendei, nāo nas profundezas do texto, mas na sua superfície, um outro discurso - o de lalangue, a língua oral - considerei-a também de uma perspectiva ontológica, surpreendendo esse "homem muito antigo" na sua pré-história existencial, em que língua e leite são os pólos da comunicação.

\section{ESPAÇO TRANSICIONAL}

E para continuar seguindo no texto as pegadas da criança, vou me deter em dois aspectos da produção literária que remontam às suas primeiras incursões no mundo: o espaço de transição entre o interior e o exterior - essa terra de ninguém onde pela primeira vez algo se cria - e um outro espaço, que vou considerar preliminarmente como sendo o da representação, uma vez que já envolve a mediação da linguagem, onde se recria algo, pela primeira vez.

São experiências próximas uma da outra no desenvolvimento da criança. Não se excluem, nem se confinam na infância, ao contrário, são o germe da vida cultural.

48. Apud RAMOS, 1985. p.211.

49. Idem. 221. 
No primeiro caso, que é primeiro também na história pessoal, lembro aqui o objeto transicional - nome dado por Winnicott $\mathrm{t}^{50}$ a tudo aquilo que, como o seio materno, pertence ao mundo exterior mas é interiorizado pela criança que, nessa fase, ainda não se distingue como um corpo próprio. Freud já falara no seio como objeto alucinado, diferente, pois, do seio real. Para Winnicott, entretanto, importa o objeto real - a primeira possessão não-eu — desde que investido magicamente, de tal forma que não se define nem pela sua concretude, ainda que necessária, nem por uma existência estritamente mágica, embora constituinte. Assim, não se confunde com o conceito de objeto interno, que Melanie Klein desenvolveu como sendo um conceito mental. Trata-se de um substitutivo do objeto de desejo, com o qual a criança se funde, experimentando, pois, a condição de objeto. Mas importa observar que é dessa maneira que se desenvolve a concepção da realidade externa - um lugar de onde os objetos aparecem e no qual eles desaparecem. O bebê explora então um terceiro mundo, que não é nem a sua realidade interna, nem um fato externo.

O objeto transicional por excelência é o polegar como sucedâneo do seio, mas pode ser qualquer outro substitutivo, para sugar, morder ou enrolar, como a ponta de uma fronha, ou de uma fralda; denotando, de qualquer forma, uma relação afetiva com o mundo exterior. $E$ não é o objeto que importa - polegar, orelha, nariz, um pedaço de pano, um bichinho de pelúcia, a mão de alguém - é grande o inventário desses recursos, em geral registrados no ambiente doméstico. A sua função é traçar o limite entre o eu e o não-eu, limite que se mostra no fato de não ter a criança um poder absoluto sobre o objeto, que pode estar presente ou ausente. Ela passa, portanto, do controle onipotente, de natureza mágica, para o controle pela manipulação, que transita entre o auto-erotismo e a relação de objeto. E um dado que nos diz respeito, particularmente, é que o objeto assim constituído é uma criação da criança, não podendo, pois, lhe ser imposto. Considerem-se estas palavras de Winnicott:

É costume fazer referência ao "teste da realidade" e efetuar uma distinção clara entre apercepçăo e percepção. Reivindico aqui um estado intermediário entre a inabilidade de um bebê e sua crescente habilidade em reconhecer e aceitar a realidade. Estou, portanto, estudando a substância da ilusão, aquilo que é permitido ao bebê e que, na vida adulta, é inerente à arte e à religião." 51

50. CF. WINMICOก, 1993. p.389 e segs.

51. Idem. p.391.
Esse universo transicional, como uma terra-de-ninguém, está e não está no mundo. Caracteriza-se como uma experiência de nãointegração em que a criança se sente segura, sensação de eu sou, estou vivo, ${ }^{52}$ que a conduz ao relaxamento e, freqüentemente, ao sono. Por isso, a solidão é essencial - como observa Winnicott. ${ }^{53} \mathrm{Na}$ idade adulta, esse estado proporciona uma alienação que é ao mesmo tempo cúmplice, um estar só que é um estar pleno, uma possibilidade de gozo.

É assim que o ato de escrever funciona também como objeto transicional, não só com relação à criação literária, em geral, mas sob a forma de uma imposição, necessidade que requer uma solidão que não é como qualquer outra: "ela é feita" - diz Marguerite Duras ao falar de sua escrita. E essa solidão, ela a descreve como beatífica, na medida em que é a condição para escrever livros que ainda desconhece, que não foram determinados nem por ela mesma nem por ninguém. ${ }^{54}$

Duras explorou, ao longo de sua obra, tanto a natureza quanto os procedimentos do seu fazer artístico. E em seus comentários percebese como se equacionam o mundo interior e o exterior nesse terceiro mundo da escritura. Enquanto há os que se dizem concentrados quando escrevem, ela contesta:

não, quando eu escrevo, tenho a sensação de estar numa extrema desconcentração, eu não me possuo mais, sou um coador, tenho a cabeça furada. Não posso me explicar o que escrevo senão assim, porque há coisas que não reconheço, naquilo que escrevo. Portanto, elas me vêm de algum outro lugar, não sou eu sozinha a escrever, quando eu escrevo.

E, pois, a solidão é necessária. Para que se povoe de uma outra maneira:

Faço meus livros com os outros. O que é um tanto bizarro, é essa transformação sofrida, talvez, esse som restituído, quando isso passa por mim, mas é tudo. (...) Quanto a mim, simplesmente, eu talvez seja uma câmara de eco. ${ }^{56}$

52. Idem, 1971. p. 83.
53. Idem, 1982. p.35.
54. C. DURAS, 1993. p.19, 17 e 15.
55. DURAS, 1977. p.98.
56. DURAS, 1974. p.217-218.

REVISTA DE ESTUDOS DE LITERATURA

Belo Horizonte, $\vee .2$, p. 09 - 50, out. 94 
Novamente, essa ânsia pelo vazio de um estado diferenciado de consciência, que é, entretanto, cheio de sentido:

Estar só com o livro ainda não escrito, é estar ainda no primeiro sono da humanidade. ${ }^{57}$

Assim como Valéry, dizendo encontrar um homem muito antigo em todo verdadeiro poeta, Marguerite Duras se reporta a esse primeiro sono de um ponto de vista antropológico. Mas eu o reverto, igualmente, ao ontológico, situando-o naquele estado de não-integração em que a criança se abandona à segurança materna.

Como Duras, muitos outros escritores testemunham a necessidade da escritura, sentida até mesmo como uma relação física na prática de metapoemas, em que a palavra se torna intransitiva, sem outra referência que a sua própria materialidade, como se vê em "O Lutador", de Carlos Drummond:

$$
\begin{aligned}
& \text { Palavra, palavra } \\
& \text { (digo exasperado) } \\
& \text { se me desafias } \\
& \text { aceito o combate. } \\
& \text { Quisera possuir-te } \\
& \text { neste descampado, } \\
& \text { sem roteiro de unha } \\
& \text { nessa pele clara. }{ }^{58}
\end{aligned}
$$

Também Clarice Lispector experimenta, de uma outra maneira, essa relação:

Mas estou tentando escrever-te com o corpo todo, enviando uma seta que se finca no ponto tenro e nevrálgico da palavra. Meu corpo incógnito te diz: dinossauros, ictossauros e plessiossauros, com sentido apenas auditivo, sem que por isso se tornem palha seca. ${ }^{59}$

Essa tentativa de linguagem sem conceitos, em que o corpo e o som têm papel fundamental, eu a considero na dimensão daquilo que Winnicott chama de fenômenos transicionais - uma reminiscência doholding materno, ou seja, do suporte que a mãe dispensa à criança como garantia

57. OURAS, 1993. p.37.

58. C. ORUMUOND OE ANORADE, 1983. p. 94.

59. LISPECTOR, 1978. p. 10. do seu existir, e que se faz sentir de muitas maneiras, pela simples presença, que envolve calor e cheiro, pela voz, no tagarelar, e sobretudo no canto, no acalanto. ${ }^{60}$

Essa experiência de fusão com o mundo exterior é focalizada de outro ângulo por Guattari, quando trata do "território existencial":

Essas objetidades-subjetidades são levadas a trabalhar por conta própria, a se encarnar em foco animista: imbricam-se umas com as outras, invadem-se, para constituir entidades coletivas - meio coisa, meio-alma, meio-homem, meio-animal, máquina e fluxo, matéria e signo...61

Acrescentando que as esferas da exterioridade não são radicalmente separadas do interior, o Autor menciona "um gozo da passagem ao pari-si coletivo", cujo holding é proporcionado pelos rituais. E o uso que faço aqui desse termo, próprio do discurso de Winnicott, já atesta a associação entre essa texritorialização e os objetos e fenômenos transicionais, que asseguram por sua vez um gozo proveniente da sensação eu sou - a sensação de estar-no-mundo.

Já uma vez tive oportunidade de observar esse tipo de comunicação que se situa mais no registro semiótico do que no lingüístico, ao analisar uma passagem de $O$ Ateneu ${ }^{62}$, em que Pompéia arma uma reconstituição do ambiente doméstico, fazendo com que os pais do menino Sérgio viajem e ele, em tempo de férias, fique sozinho na enfermaria do internato, aos cuidados da mulher do diretor. Sente-se então "infantilizado no enfraquecimento, como a recomeçar a vida" e é a imagem do ninho que vai presidir às cenas seguintes.

Como já observei no caso do romance de Mário de Andrade, quando se verificam na narrativa as incursões do inconsciente a verossimilhança fica comprometida em favor da atualização fantasmática. Assim, o menino, que dois anos antes, ao entrar para o colégio, já contava onze anos de idade, acaba no colo da mulher:

60. C. WINHICOT, 1991. p. 215. Esse é um conceito fundamental, que se estende dos cuidados maternos a toda forma de apoio e segurangande que corece o sujeito: "Sempre que compreendermos profundomente um pociente a mostramos isso atrevés de umo

61. GUATTARI, 1992. p.131.

62. C. RAMOS. 1992/93. p. 29-54.

Este texto foi ampliado em conferência pronunciodo no Curso de literoturo e Psiconálise, promorido pelo Seccetorio Municipol de

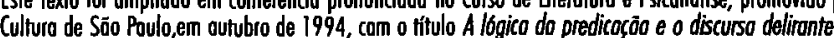


Aproximava o rosto e contava, lábios sobre lábios, mimosas historietas sem texto, em que falava mais a vivacidade sangüínea da boca, do que a imperceptível confusão de arrulhos cantando-lhe na garganta como um colar sonoro. ${ }^{63}$ (Grifo adicionado).

Esse clima de lalangue é o do acalanto, em que o la-la-rá do adulto se confunde com a lalia da criança, resumindo-se o texto, quando há, a um puro jogo de significantes, anterior ao "jogo do significante", que pressupõe uma cadeia, o Outro e um significado barrado. É interessante lembrar aqui a informaçāo dos irmãos Villas-Boas sobre o acalanto entre os indígenas, que não compreende nunca nenhum texto:

a canção se resume a uma melodia ciciada no ouvido da criança. ${ }^{64}$

E é exatamente essa intimidade que o Narrador de O Ateneu evoca, ao referir-se explicitamente ao acalanto:

Tomava-me ao colo, acalentava-me, agitava-me contra o seio como um recém-nascido, inundando-me de irradiaçóes quentes de maternidade, de amor. ${ }^{65}$ (Grifo adicionado).

A partir do texto de Drummond, cuja obsessão pela escritura por si só já a caracterizaria como uma reminiscência do objeto transicional manifestação positiva, como observou Winnicott ao mencionar os efeitos culturais dessa experiência - evoluimos, pois, para a referência a um determinado tipo de linguagem que compreende também os fenômenos transicionais.

E antes de prosseguirmos nas pegadas da criança, focalizando aquele outro momento de sua incursão no mundo, caracterizado pelo uso da linguagem, gostaria de acrescentar mais um exemplo desse vício de escrever, que chega a sobrepor a escritura à vida.

No prefácio de Monteiro Lobato ao livro de contos de Godofredo Rangel - Os humildes - faz o escritor esta surpreendente confissão

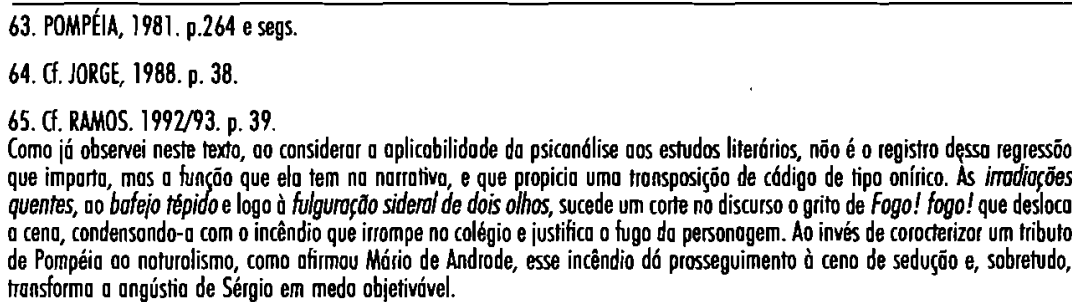

relativamente a uma amizade que se prolongava já por várias décadas através da troca de cartas:

Nas raras vezes em que nos encontramos no decurso de trinta anos sentimo-nos constrangidos um diante do outro, sem facilidade no dizer - e com uma grande vontade de separar-nos novamente e novamente retornarmos à correspondência. Não somos amigos falados, somos amigos escritos. (grifo acrescentado) ${ }^{66}$

Escrever é, portanto, um vício. Barthes é mais incisivo:

a tagarelice do texto é.apenas essa espuma de linguagem que se forma sob efeito de uma simples necessidade de escritura. ${ }^{6 /}$

Como vimos, Winnicott diz que é a substância da ilusão que caracteriza o espaço transicional, e essa é a fonte da atividade artística, da filosofia, da religião e de toda a criatividade científica, desde que se verifique um desenvolvimento saudável do sujeito. Mas há também um lado negativo, que se manifesta sob formas diversas, como por exemplo o fetichismo e a adição. Joyce McDougall, ao considerar alegoricamente a patologia de seus clientes numa dramaturgia do eu, desenvolve o pensamento de Winnicott, analisando aspectos do que chamou teatro transicional. b8

Assim como a criança faz da mão ou da orelha da mãe — ou de quem lhe faça as vezes - o seu objeto transicional, escravizando-a, portanto, junto de si até adormecer, a fixação de tal comportamento se mostra também em adultos, que não podem prescindir da manipulação de um Outro que lhe assegure aquele estado de não-integração proporcionado pela proteção materna. O "eu sou", o "estou vivo", dependem da sujeição de alguém, que não sendo um objeto, mas um outro sujeito, torna conflituosa a relação. Trata-se de uma dependência, uma modalidade de adição, como a que se verifica com a bebida ou uma droga qualquer.

O escrever, já vimos que é um vício. Uma necessidade. Marguerite Duras vai mais longe:

Pode-se falar numa doença do escrever. ${ }^{69}$

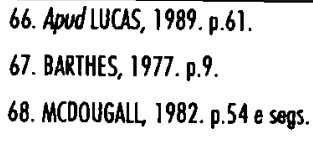

69. DURAS, 1993. p. 64 
E é assim que o objeto e os fenômenos transicionais interessam aos estudos literários, não apenas neste caso de nos fazer compreender que haja escrita sem referência - uma desobjetivação do objeto, que se dissemina em muitos outros, ${ }^{70}$ como sucede com a poesia - mas também para nos situar diante de obras complexas - atividade que vai dos versos à ficção, às cartas, à crítica e aos diários íntimos, num afã de escrever que se mostra até mesmo em uma produção simultânea, sob pseudônimos vários, como é o caso de Fernando Pessoa, na poesia, e de Raul Pompéia, na crônica literária. A compulsão à escrita se manifesta, pois, como uma dependência, de que Drummond nos dá este belo testemunho:

$$
\begin{aligned}
& \text { Lutar com palavras } \\
& \text { é a luta mais vã. } \\
& \text { Entanto lutamos } \\
& \text { mal rompe a manhã. }
\end{aligned}
$$

A solidão está implícita nesse comportamento, forma positiva da adição que Duras compara, entretanto, ao alcoolismo, de que foi vítima:

A solidão, isto quer dizer também: Ou a morte, ou o livro. Mas antes de tudo, isto quer dizer o álcool. Whisky, isto quer dizer. ${ }^{72}$

\section{COMPULSÃO À REPETIÇÃO}

Consideremos agora o outro estágio do desenvolvimento, em que já se manifesta a mediação da linguagem. O que chama a atenção, de início, é a descoberta da representação, que se registra neste fato relatado em Além do princípio de prazer ${ }^{73}$ - qualquer coisa como o Aha-Erlebnis ${ }^{14} \mathrm{da}$ função simbólica, que Freud surpreendeu na brincadeira de uma criança que balbuciava ainda as suas primeiras palavras. Enquanto aguardava a chegada da mãe do menino (que aliás era seu neto), observou que ele

70. BADIOU, 1994. p. 78: "EE ñ̃o somente o poemo nóo tem objeto, mos uma grande parte de suo operascóo visa precisamente renegar o objeto; fazer com que o pensomento dedare o que hó no destitivic̄o de todo objeto suposto. Tal é o cerne da experiênci

71. DRUMMOND DE ANDRADE, 1983. p. 90

72. DURAS, 1993. p.23.

73. Cf. FREUD, 1976. Vol. XVIII, p.25-28.

74. Cf. LACAN, 1966. p.93. Analisando o comportamento de umo crionso, entre os seise dezoito meses, que dionte do espelho jó é crpoz de reconhecer o sua imogem, obsevv: "Reconhecimento ossinolodo pelo mímico iluminativa do Aho Enebnis (experiênn manipulava um carretel enrolado numa linha. Mas não o puxava como a um carrinho: lançava-o ao berço, onde ele desaparecia entre o cortinado, enquanto exclamava um óóóó!..., e depois puxava-o de novo, em meio a outra exclamação: dáááá!... Esse jogo se repetia, sempre o mesmo gesto, sempre as mesmas manifestações, até que ele se deu conta de que a criança usava o carretel para representar a mãe ausente — fort em alemão significa fora - e também a mãe presente: da quer dizer aqui. ${ }^{75}$ Antes disso, já se observara na casa que a criança tinha o hábito de jogar seus brinquedos para debaixo dos móveis, sempre com a mesma exclamação de óóó! Faziaos, pois, desaparecer.

Esse jogo, que constituía, pois, uma dramatização da ausência e da presença da mãe, assinalaria já o domínio da linguagem, por transformar-se o objeto em significante, do mesmo modo que a ação de lançar e de puxar era investida simbolicamente. A preocupação de Freud, porém, era outra, interessado que estava em saber por quê a criança se ocupava em repetir insistentemente uma experiência que lhe era desagradável, quando podia divertir-se de outras maneiras. Concluiu, então, que saindo de uma atitude passiva diante do fato, para assumir um papel ativo, ela adquiria controle sobre a perda, manipulando-a à vontade, e ainda experimentava a alegria do reencontro, que era saudado com júbilo. A repetição trazia, pois, uma produção de prazer de outro tipo.

Como todo ato criativo faz lembrar a arte, Freud estendeu imediatamente essas reflexóes à atividade artística, observando ainda que

a representação e a imitação artísticas efetuadas por adultos, as quais, diferentemente daquelas das crianças, se dirigem a uma audiência, não poupam aos espectadores (como na tragédia, por exemplo) as mais penosas experiências, e, no entanto, podem ser por eles sentidas como altamente prazerosas. ${ }^{76}$

E considerando que a produção de prazer é nesse caso o seu resultado final, acabou por sugerir que o tema fosse tratado por "algum sistema de estética", já que, diferentemente do que acontece no campo psíquico, não pressupōe o funcionamento de tendências além do princípio de prazer, onde ocorrem outras, mais primitivas. Voltaremos a essa questão, para analisar mais detidamente essa "diferença". Por ora lembro que, apesar

75. Tradurgōes opressodos registrom ali .Mos o advérbio da significo tonto ló quanto có. Vejam-se estos expressōes: Da bin ich (aqui estou) e o contrório: Hier und da (có e ló́).

76. FREUD, 1976. p.29. 
de Freud haver registrado que, ao contrário do que acontece na brincadeira infantil, a imitação artística é dirigida a uma audiência, o ponto principal dessa relação me parece ter sido desconsiderado por ele: é que no caso da criança o que se repete é uma experiência própria, enquanto na tragédia repete-se, pelo menos em princípio, uma experiência alheia, não só ao espectador, mas sobretudo ao autor do texto (Esta é uma questão à qual voltaremos). Eu moveria, pois, o foco da colocação, de modo a considerar o fato penoso na esfera da experiência do próprio escritor. Como no caso dos poetas, por exemplo. Tantos são os versos que exploram a perda, o abandono, o sofrimento, que me permito lembrar aqui uma caricatura uma trova popular que me vem da infância:

\section{Qual seria o anel do Poet \\ se o Poeta fosse doutor? \\ Uma saudade chorando \\ na cravação de uma dor}

Um fato que veio perturbar a teoria de Freud sobre a atividade onírica é, sem dúvida, a caracterização dos sonhos traumáticos, que ele discute nesse texto que estamos considerando. E é curioso que o tema não tenha sido objeto de análise em outros ensaios, sobretudo os que tratam especificamente dos sonhos. Talvez porque, não cabendo eles nem nos sonhos de ansiedade, nem nos sonhos de castigo, em que um sentimento de culpa pode encontrar satisfação através da punição adequada, ficassem à margem, como uma exceção ao princípio de que a atividade onírica está relacionada com a satisfação de desejo:

É, porém, impossível classificar como realizaçōes de desejo os sonhos que estivemos debatendo e que ocorrem nas neuroses traumáticas, ou os sonhos tidos durante as psicanálises, os quais trazem à lembrança os traumas psíquicos da infância."

Para Freud, a compulsão à repetição é, portanto, algo mais primitivo, mais elementar e mais instintual ${ }^{78}$ do que o princípio de prazer que ela domina, e os sonhos traumáticos se justificariam por tal comportamento compulsivo.

Creio que é igualmente a compulsão à repetição que leva o poeta

\section{Idem, p.48.}

78. Como venho citando o texto de Freud na Ediç̄ó Stondard Brosileiro, mantive o termo instintual, apesar de outros traduç̄es

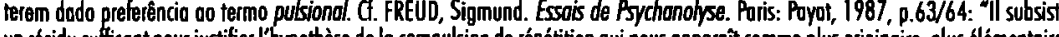
plus pulsionnelle que le principe de plaisir qu'elle met à l'écont." a trazer constantemente de volta a experiência traumática, independentemente do prazer advindo da posição ativa assumida perante a experiência, e que permite manipulá-la através de um procedimento estético. Estes versos - fragmento de um dos mais conhecidos poemas de Drummond - são exemplares, pois não só atualizam a experiência, como o fazem por meio de insistente repetição que se estende até o fim do poema:

No meio do caminho tinha uma pedra

tinha uma pedra no meio do caminho

tinha uma pedra

no meio do caminho tinha uma pedra.

A ausência, quase sempre ligada à morte, é dos temas mais freqüentes na poesia lírica, e por vezes a perda se elabora num cenário em que se dá igualmente uma repetição, uma volta ao lugar da experiência. Lembrem-se a "Visita à casa paterna", onde Luís Guimarães Júnior diz que

Gemia em cada canto uma saudade -

e uma outra visita - a de Machado de Assis, ao túmulo de sua Carolina:

Querida, ao pé do leito derradeiro

Em que descansas desta longa vida

Aqui venho e virei, pobre querida,

Trazer-te o coração do companheiro.

É também a morte que Camōes celebra neste soneto:

Alma minha gentil, que te partiste

Tão cedo desta vida descontente

Descansa lá no céu eternamente

E viva eu cá na terra sempre triste.

Em "A mesa", Drummond revive a perda da família e convoca os pais para uma comemoração "junto da mesa / vazia."

Borges se volta, igualmente, para a morte do pai:

La lenta parca fue cortando el hilo

Te hemos visto morir sonriente y ciego.

E o desaparecimento da família é ainda o tema de Manuel Bandeira, quando 
evoca a festa de São João:

Hoje não ouço mais as vozes daquele tempo (...)

Onde estão todos eles?

- Estão todos dormindo

Estão todos deitados

Dormindo

Profundamente.

Se nesses versos a expressão é serena, o mesmo não acontece nesta estrofe de Jorge de Lima:

E esta angústia de te recompor, traço

a traço, tua boca dolorosa

(fonte que se exauriu), teu rosto escasso,

ó musa angelical e airosa rosa!

Esses são exemplos que me acudiram espontaneamente, e não se justificaria pesquisar outros, pois são inumeráveis e povoam, por certo, a memória do leitor. Mas eu gostaria de lembrar ainda um outro aspecto da produção literária em que o sofrimento tem um relevante papel.

Trata-se da poesia popular, acompanhada quase sempre de música, em cujos versos a perda e a ausência não se devem em geral à morte, mas ao abandono.

É lugar-comum na canção popular a atualização da dor, com ênfase nas lágrimas derramadas, como nestes versos de Noel Rosa:

\section{Você partiu \\ saudade me deixou \\ eu chorei. (...) \\ O nosso amor foi uma chama \\ que o fogo do passado desfaz \\ agora é cinza, tudo acabado \\ e nada mais.}

A diferença que importa observar entre canções desse tipo e os textos que acabamos de ver não está no tratamento do tema, ou seja, no rótulo de popular, mas no fato de que, apesar de líricos, se situam numa dimensão em que o Outro exerce um papel fundamental.

Como no caso da tragédia, lembrado por Freud, tal produção exorbitaria da experiência individual. Mas não se pode esquecer que o $e u$ que aí se expressa é um eu social . A esse propósito, gostaria de trazer aqui esta observação de Guattari, feita a partir da "subjetividade polifônica" de Mikhail Bakhtine:

Do mesmo modo que as máquinas sociais que podem ser classificadas na rubrica geral de Equipamentos Coletivos, as máquinas tecnológicas de informação e de comunicação operam no núcleo da subjetividade humana, não apenas no seio das suas memórias, da sua inteligência, mas também da sua sensibilidade, dos seus afetos, dos seus fantasmas inconscientes.

E tanto a canção popular quanto a tragédia grega participam dessa função maquínica, a primeira ligada à tecnologia da midia e do mercado, a segunda produzida pelo aparelho de Estado que era a sociedade helênica, sustentada pelos seus mitos e ritos, pelos concursos públicos que centralizavam a produção teatral - metáfora paterna a atuar diretamente sobre os fantasmas do povo.

Considerando os Agenciamentos coletivos de enunciação, Guattari propõe a seguinte definição de subjetividade:

o conjunto das condições que torna possível que instâncias individuais e/ou coletivas estejam em posição de emergir como território existencial auto-referencial, em adjacência ou em relação de delimitação com uma alteridade ela mesma subjetiva. ${ }^{80}$

E não há razão para supor que a experiência dessa imago não esteja igualmente sujeita à compulsão à repetição, tanto quanto ao prazer que deriva da posição ativa assumida diante da dor. De outro modo não se compreenderia que uma experiência traumática, que a lógica levaria a esquecer, ou a ocultar, fosse insistentemente celebrada e propalada aos quatro ventos. Isto vale, creio eu, tanto para a canção popular quanto para a tragédia, cuja economia não pode, portanto, ser tratada por "algum sistema de estética" desvinculado das forças pulsionais mais primitivas.

O que é preciso lembrar, porém, é o fato de que o tratamento artístico de um tema qualquer constitui já uma elaboração que, como vimos, é assistida tanto pelo dionisíaco quanto pelo apolíneo - e assim, na medida em que o poeta atualiza o fato traumático no processo de criação literária, distancia-se dele, independentemente de tratar-se aí de um sujeito individual ou coletivo. Uma perspectiva já então se estabelece. A compulsão

79. GUATARI, 1992. p.14.

80. Idem. p. 19 . 
à repetição é o móvel dessa atividade, como a expressão indica, mas repetir é aí algo mais complexo do que a atualização do passado: é antes dominálo, exorcizando-o; é submeter a experiência à diferença e é situar-se, afinal, na dimensão do princípio de prazer, ainda que o fazer artístico seja, como se sabe, o menos razoável dos jogos.

Tornando ao episódio relatado por Freud, vimos que o menino que ele surpreendeu brincando com o carretel fazia desse objeto uma representação da mãe - o que o caracterizaria como um significante do mesmo modo que fazê-lo desaparecer e reaparecer seria um ato investido de função simbólica para a sua ausência e presença, o que instituía esse momento como ato inaugural da inserção da criança no registro simbólico. E a experiência não se reduzia a uma semiótica do objeto, pois ela já associava a ação a signos verbais, apreendidos de maneira rudimentar, para marcar os dois tempos do jogo, conquistados através da passagem de um comportamento passivo a um comportamento ativo: o tempo da tristeza e o da alegria.

Mas sucede que a criança, apesar de inserida no universo dos signos, conserva uma concepção mágica do mundo, paralelamente à relação de objeto, de tal forma que o carretel - objeto da realidade exterior que ela manipula - não é, neste caso, apenas um significante da mãe. No espaço transicional da ilusão o carretel é também ela própria, devendo-se entender esse ela tanto relativamente à mãe quanto a uma auto-referência. ${ }^{81}$

As brincadeiras das crianças nos proporcionam ensinamentos, mesmo quando não estamos a observá-las. Certo dia distante, por exemplo, eu me dirigia ao fundo da casa, levando uma pilha de roupas nos braços, e minha filha, que tinha pouco mais de dois anos, estava parada no caminho, em seu velocípide. Como ela não saísse do lugar, fui dizendo, impaciente: - Não está vendo que eu preciso passar? E ela me respondeu no mesmo tom: - Não está vendo que o sinal está fechado? Muitas vezes refleti sobre esse curioso diálogo. Primeiramente, minha pergunta fora estúpida, sem propósito: por que haveria ela de ver a minha pressa? Mas a sua resposta, esta me foi reveladora: ela não estava guiando o velocípide, mas o carro, como sua mãe. E o carro pára nos sinais. E o sinal estava fechado.

Assim, carretel / mãe / criança: uma coisa só; velocípide / carro /

81. Essa auto-referêncio foi observodo por Locon segundo a ótico do objeto pequeno 0 : o corretel não é uma reduçáo da mãe como nas bruxarios dos Jivaras, mas uma caisa qualquer do sujeito que dele se destoca, sem deixor entretonito de a ele pertencer. Se, poro Asistóteles, o homem penso com o seu objeto, éc com o seu objelto que o ciongro salto os fronteiros do seu domínio tronsformado em poşa e é aí que comesa o encontamento. Senda o significonte a primeiro morca do sujeito, $t$ o corretel que o designa como objeto pequeno a. C. LACAN, 1973. p.60. criança / mãe: uma coisa só. Trata-se de uma operaçăo que independe de aprendizado. Será mesmo que se verifica aí uma representação, ou o mundo é apreendido por experiência direta, o que nos faz repensar novamente a natureza da metáfora?

A manipulação da linguagem, que faz o fort / da tão festejado, constituindo, como há pouco observei, o Aha-Erlebnis da função simbólica, acaba não tendo aí essa extraordinária importância, pois os signos óóó e dááá não representam nada, apenas reduplicam verbalmente a ausência e a presença que “de fato" se dão.

O mais relevante nesse episódio continua a ser o holding proporcionado pelo brincar, do mesmo modo que, na idade adulta, assume ele novas manifestações, como o escrever, quando então se investe de uma função representativa, apesar de, muitas vezes, nada representar.

\section{DO RETORNO INTERDISCIPLINAR}

E agora, é preciso parar de escrever.

Compromisso difícil de assumir, porque fica a sensação de estar diante do mar, com um balde de água nas mãos. A interlocução literatura / psicanálise se faz em cada verso, em cada página de ficção, em cada obra teatral. Sófocles, Dante, Cervantes, Proust, Shakespeare, Camões, Goethe, Machado de Assis, Fernando Pessoa, Joyce, Drummond, Guimarães Rosa, Noel, Caetano, Chico - isto não é uma seleção para amostragem. São evocações afetivas que me ocorrem ao pensar que é de psicanálise que estamos falando.

Mas o objetivo destas reflexões, eu revelei de início: são os os estudos literários, particularmente, aqui, os estudos interdisciplinares. E depois de perpassar esses caminhos emaranhados, me faço uma pergunta: a quem interessam estes estudos?

Os nossos estudantes recebem informações, mas não ficam habilitados a desenvolver pesquisas nesse campo, a não ser mediante um esforço próprio, extracurricular. Uma iniciação nos estudos psicanalíticos demanda tempo e, como vimos, outros pré-requisitos. Não é numa Faculdade de Letras que eles vão receber essa formação. O que o professor pode fazer, nesse caso, é divulgar o seu trabalho, fornecendo bibliografia e discutindo conceitos básicos, como de resto vão fazer aqueles que se 
dedicam à interlocução com outras diciplinas.

Mas há outros estudantes - os de psicologia, por exemplo, sobretudo os que se dirigem à psicanálise - que por sua vez devem estar familiarizados com a literatura e os estudos literários.

Para isto, segundo reivindicação de Freud, além de outros conhecimentos, são necessários os de mitologia e de crítica literária, aos quais Lacan acrescentou a gramática (a lingüística?), a retórica e a poética, ao tratar da formação analítica. ${ }^{82}$

Como observa Joël Dor, mais importante do que a anamnese e a investigação armada, que se apóia em recursos técnicos e instrumentais, é o material clínico fornecido pelo paciente na prática psicanalítica:

A única técnica de investigação de que o analista dispõe é a sua escuta. Tanto quanto caduca a noção de investigação armada, permanece essencialmente verbal o material clínico fornecido pelo paciente. Será, então, de imediato na dimensão do dizer e do dito que se delimitará o campo de investigação clínica.

Ora, como sabemos, esse espaço de palavra está saturado de "mentira" e tem o imaginário como parasita. De fato, é o lugar onde vem se exprimir o desdobramento fantasmático; é também aquele em que o sujeito dá testemunho de sua própria cegueira, já que não sabe realmente o que diz através do que enuncia, do ponto de vista da verdade do seu desejo, do ponto de vista, então, daquilo que subentende o sintoma em seu travestimento.

Esse espaço de palavra saturado de "mentira" não é outro senão o do discurso retórico. $\mathrm{O}$ analisando quer persuadir o analista e, antes de tudo, a si próprio. Quanto ao discurso literário, este é mais sutil, pois os recursos retóricos se submetem a uma poética que organiza o texto e lhe confere estatuto estético mediante um código próprio. Mesmo assim, vimos como se dá o desdobramento fantasmático nas "interpolaçōes" de caráter onírico analisadas em Amar, verbo intransitivo e Vila dos Confins, do mesmo modo que no poema de Valéry essa instância se mostra na superfície do jogo do significante.

Mas assim como para analisar o discurso literário não basta ler as obras como qualquer diletante, para decodificar o discurso do paciente é preciso algo mais do que a leitura de textos literários. E esse algo mais o estudante da área psicanalítica tem que buscar também por iniciativa

82. Idem. 1966. p.288.

83. DOR, 1994. p.14 própria, em estudos extracurriculares

Eis um círculo vicioso que não deve, entretanto, desanimar-nos.

Já que os currículos estão aí para serem executados, ao invés de idealizar condições exemplares, melhor é que nos atenhamos ao possível, juntando nossos fragmentos de formas e cores a esse imenso painel dos estudos interdisciplinares. Em geral o que queremos é ver luz no fim do túnel, como se este estivesse sempre aí, disponível, e nos esquecemos de que, muitas vezes, temos de cavá-lo com as próprias mãos.

REFERÊNCIAS BIBLIOGRÁFICAS

ANDRADE, Mório de. Amar, verbo intransitivo. Sōo Poulo: Livrorio Martins Editoro, s/doto. ARISTOTE. Poétique. Poris: Les Belles Lettres, 1952

AUSTIN, L J. Apud WANDERLEY, Jorge (trod. e prefácio) O cemiténo morinho. Sōo Poulo: Max Limonod, 1984 BADIOU, Alain. Paro uma nova teorio do sujeito. l.ed. Rio de Joneiro: Relume/Dumaró, 1994. o prozer do texto. Sóo Paulo: Perspedtivo, 1977 .

BORGES, Jorge Luis. Lo Poesio. In: Obros completos de Jorge Luis Borges. Vol.III. Buenos Aires: Emeré Editores, 1989. CAllLOSS, Roger. Le mythe et I'Homme. Paris: Gollimard, 1972

CHENG, Fronçois. L'écriture poétique chinoise. Poris: Sevil, 1977

DERRIDA, Jacques. Lo pharmocie de Ploton. in: Tel Quel. Poris. Hiver. 1968

DOR, Joêl. Estruturas e cllinica psicanolficico. Rio de Joneiro: Tourus Editoro, 1994.

DRUMMOND DE ANDRADE, Corlos. O Lutodor.In: Novo Reunicioo. Rio de Joneiro: José Olympio / Pro-Memória/INL, 1983.

DURAS, Marguerite \& GAUTHIER, Xovière. Les Parleuses. Poris: Minuit, 1974.

DURAS, Marguerite \& PORTE, Michelle. Les lieux de Marguerite Duros.Poris: Minuit, 1977

DURAS, Marguerite. Ecrire. l.ed. Poris: Gollimard, 1993.

REEDD, Sigmund. Obro Completo. A interpretatá̧áo dos sonhos. Vol. IV. Rio: Imago, 1972

- Obro Completo. A interpretação dos sonhos. Val. V. Rio de Janeiro: Imogo, 1972

Obro Completo.. Alem do principio de prozer/Psicologio de Grupo. Vol. VIII. Rio de Joneiro: Imogo, 1976.

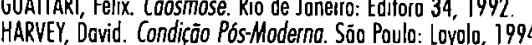

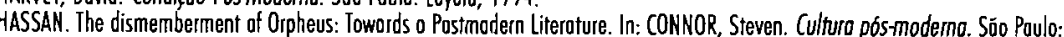
Loyolo, 1993.

INGARDEN, Roman. Dos litererrische Kunstwerk. Tubingen: Mox Nienmeyer Verlog, 1960.

JORGE, Anó Lúcia Covoni. O ocolonto e o horror. Sấa Pula: Escuto, 1988.

LACAN, Jacques. Fonction et champ de to parole et du longage. In: Eerisis. Paris: Seuil, 1966. 
Linstonce de lo leftre dons línconscient. In: Ecrits. Po . Sevil, 1966

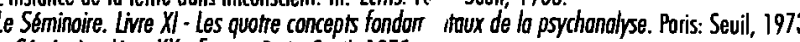
Seminaire. Live XX - Encore. Paris: Seuil, 1975

. Le stade dy miroir. In: Ecrits. Poris: Sevil, 1966

ISPPECTOR, Qorice. Aguo viva. Rio de Joneiro: Nowa Fronteira, 1978.

OBBATO, Monteiro, Apud LUCAS, Fóbio. Aspectos literórios de Monteiro Loboto. In: Do Barroco oo Moderno. Söo Paulo: Ático, 1989.

MONTAG, Warren, 0 que estó em jogo no debote sobre o pós-modernismo? In: KaPLAN, E. Ann, (org.). 0 Matestar no Pós-

$$
\text { jiodma Teixeira de. Um diognóstico poro Tito. In: Cenório. N.3. Bela Horizonfe: GREP (Grupa de Estudos Psicanalfíicos). }
$$

$$
1994 .
$$

PALMÉRIO, Mório. Vila dos Confins. Rio de Joneiro: José Olympio, 1956.

PLATÃO. Phedre. In: Oecvres completes de Ploton. Paris: Gollimord, 1950.

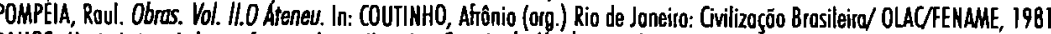
RAMOS, Mario Luizo. A desmifificaço do sotélite. In: Correio do Manhäa, Rio de Joneiro, 17/10/1964. Suplemento literório. Além do prinćpio de imoginoşōo. In: WalTY, lvete Comorgos e OLIVEIRA, Luiz Qóudio Vieiro de (org.) Ensoios de Semiotica. N. 12. Belo Horizonte: FALE/UFMG, 1984

aspectos do Romanceiro do inconfidencia. In: Tendêncio. N. 3. Belo Horizonte, 1960

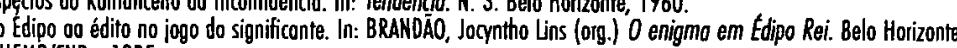
JFMG/CNPq, 1985

Documento e tantosmo em 0 Areneu. In: Ensoios de Semiotica. N. 26. Belo Horizonte: FALE/UFMG, 1992/3.

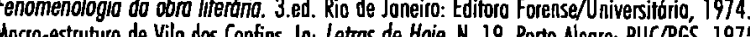

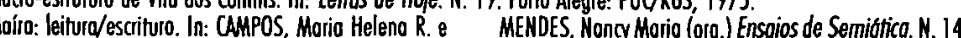
Belo Horizonte: FALENFMG, 1985

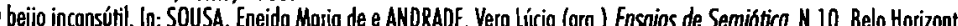
FALENJFMG, 1983

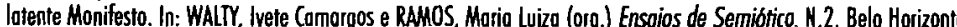
FALE/UFMG 1979.

Os avessos da linquagem. Belo Horizonte: Preféituro Municipol de Belo Horizonte, 1990.

sicologia e estetica de Raul Pompéio. Belo Horizonte: ed. própria, 1957.

Un modelo poético. In: CampOS, Morio Heleno R. e MENDES, Noncy Morio. (org.) Ensaios de Semiática. N.14.

Belo Horizonte: FALECNFMG, 1985

Varioģäes sobre o trovessia. In: CAMPOS, Morio Heleno R. e MENDES, Noncy Morio (org.). Ensoios de Semiofica N. 6. Belo Horizonte: FALENFFG, 1981.

VALĹRY, Poul. Apud: KERMODE, Frank Um apeitie pelo poesio. Sõo Poulo: Edusp, 1993

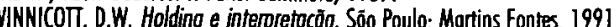

0 ambiente e os processos de maturogáa. Porto Alegre: Artes Médicos, 1982

io de Joneiro: Imogog, 1971

STIK Joś

WISWIK, José Miguel. 0 som e o sentido. Söo Poulo: Componhio das Letros, 1989.

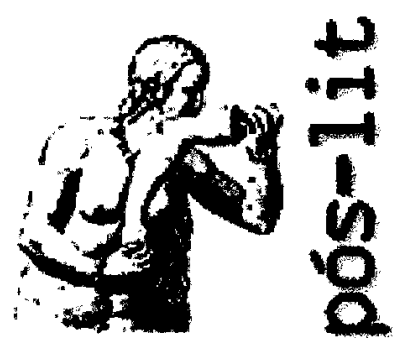

\section{Programa de Pós-Graduação em Letras: Estudos Literários da Faculdade de Letras da UFMG}

Artigo disponível em http://www.letras.ufmg.br/poslit 